\title{
Peningkatan Hasil Belajar Bahasa Indoneia melalui Metode DRTA (Directed Reading Thingking Activity)
}

\author{
Yamini $^{1}$ \\ ${ }^{1}$ SD Negeri 1 Pandean Trenggalek \\ Email: ${ }^{1}$ yamini@gmail.com
}

\begin{tabular}{l}
\hline Tersedia Online di \\
\hline http://www.jurnal.unublitar.ac.id/ \\
index.php/briliant \\
\hline \\
\hline Sejarah Artikel \\
\hline Diterima pada Februari 2018 \\
Disetuji pada Februari 2018 \\
Dipublikasikan pada 13 Februari \\
2018 Hal. 120-127 \\
\hline
\end{tabular}

Kata Kunci:

hasil belajar, bahasa indonesia, drta,

\section{DOI:}

http://dx.doi.org/10.28926/briliant .v3i1.

\begin{abstract}
Abstrak: Rendahnya hasil belajar bahasa Indonesia salah satu penyebabnya adalah pembelajaran Bahasa Indonesia cenderung kepada pembelajaran bersifat konvensional yaitu hanya menggunakan metode ceramah, sedangkan pada hakekatnya pembelajaran Bahasa Indonesia menuntut siswa dapat berpartisipasi aktif dalam pembelajaran, siswa dapat mencari dan menemukan masalahnya sendiri. Subjek Penelitian tindakan kelas ini pada siswa kelas III SDN 1 Pandean Kecamatan Dongko dengan jumlah siswa sebanyak 23 siswa terdiri dari 10 siswa laki-laki dan 13 siswa perempuan. Hasil penelitian menunjukkan metode DRTA dapat meningkatkan hasil belajar yang ditunjukkan dengan nilai studi awal hanya 56,52 naik menjadi 66,96 pada siklus pertama, dan 78,26 pada siklus kedua, dengan tingkat ketuntasan belajar sebanyak 4 siswa $(17,39 \%)$ pada studi awal, $65,22 \%$ atau 15 siswa pada siklus pertama, 22 siswa atau $95,65 \%$ pada siklus kedua.
\end{abstract}

Dalam pendidikan formal, bahasa diajarkan meliputi empat keterampilan berbahasa. Keempat komponen tersebut adalah keterampilan menyimak, keterampilan berbicara, keterampilan membaca dan keterampilan menulis. Setiap keterampilan itu erat pula berhubungan dengan proses berpikir yang mendasari bahasa. Bahasa seseorang mencerminkan pikirannya.Semakin terampil seseorang berbahasa, semakin cerah dan jelas pula jalan pikirannya. Keterampilan hanya dapat diperoleh dan dikuasai dengan cara praktek dan banyak latihan. Melatih keterampilan berbahasa berarti pula melatih keterampilan berpikir.

Pada aspek berbicara, fokus utama pelajaran ini kepada kemampuan siswa dalam berbicara secara efektif dan efisien untuk mengungkapkan gagasan, pendapat, kritikan, perasaan, dalam berbagai bentuk kepada berbagai mitra bicara sesuai dengan tujuan dan konteks pembicaraan. Keterampilan berbicara harus dikuasai oleh para siswa SD karena keterampilan ini secara langsung berkaitan dengan seluruh proses belajar siswa di SD. Keberhasilan belajar siswa dalam mengikuti proses kegiatan belajar mengajar di sekolah sangat ditentukan oleh penguasaan kemampuan berbicara mereka. Siswa yang tidak mampu berbicara dengan baik dan benar akan mengalami kesulitan dalam mengikuti kegiatan pembelajaran untuk semua mata pelajaran.

Bahasa berperan sangat penting dalam kehidupan manusia. Hal ini sesuai dengan pendapat Widyamartaya (1989:11) yang menyatakan bahwa bahasa merupakan sarana atau alat bagi manusia untuk mengekspresikan diri. Salah satu keterampilan berbahasa adalah bercerita. Permatasari (2009:18) menyatakan 
bahwa bercerita merupakan aktivitas menuturkan sesuatu yang mengisahkan tentang perbuatan, pengalaman, atau suatu kejadian yang sungguh-sungguh terjadi atau rekaan.

Bercerita memiliki manfaat yang besar bagi anak-anak. Sesuai dengan Sudarmadji, dkk. (2009: 5-9) menyatakan bahwa bercerita pada anak-anak memiliki beberapa fungsi yang sangat penting, yaitu sebagai (a) kontak batin, (b) media penyampai pesan moral dan nilai, (c) pendidikan imajinasi/fantasi, (d) pendidikan emosi, (e) membantu proses identifikasi diri dan perbuatan, (f) memperkaya pengalaman batin, dan (g) hiburan dan penarik perhatian. Dengan demikian, aktivitas bercerita perlu dilatih dan dikembangkan pada peserta didik.

Namun, harus diakui secara jujur, keterampilan berbicara dikalangan siswa sekolah dasar, khususnya keterampilan bercerita, belum seperti yang diharapkan. Kondisi ini tidak lepas dari proses pembelajaran bahasa Indonesia di sekolah yang dinilai telah gagal dalam membantu siswa terampil berpikir dan berbahasa sekaligus, yang lebih memprihatinkan, ada pihak yang sangat ekstrim berani mengatakan bahwa tidak ada mata pelajaran Bahasa Indonesia pun siswa dapat berbahasa Indonesia seperti saat ini, asalkan mereka diajari berbicara, membaca, dan menulis oleh guru. Sementara itu, prestasi observasi empirik di lapangan juga menunjukkan fenomena yang hampir sama. Keterampilan bercerita siswa SD berada pada tingkat yang rendah, diksi (pilihan kata)-nya kurang, kalimatnya tidak efektif, struktur tuturannya rancu, alur tuturannya pun tidak runtut dan kohesif. Demikian juga keterampilan berbicara siswa kelas III SDN 1 Pandean Kabupaten Trenggalek.

Berdasarkan hasil pada kegiatan prasiklus hanya 17,39\% (4 siswa) dari 23 siswa yang dinilai sudah terampil bercerita dalam situasi formal di depan kelas. Indikator yang digunakan untuk mengukur keterampilan siswa dalam bercerita, di antaranya kelancaran berbicara, ketepatan pilihan kata (diksi), struktur kalimat, kelogisan (penalaran), dan kontak mata. Minimalnya terdapat dua faktor yang menyebabkan rendahnya tingkat keterampilan siswa dalam bercerita, yaitu faktor eksternal dan faktor internal. Yang termasuk faktor eksternal, di antaranya pengaruh penggunaan bahasa Indonesia di lingkungan keluarga dan masyarakat. Dalam proses komunikasi sehari-hari, banyak keluarga yang menggunakan bahasa ibu (bahasa daerah) sebagai bahasa percakapan di lingkungan keluarga. Demikian juga halnya dengan penggunaan bahasa Indonesia di tengah-tengah masyarakat. Rata-rata bahasa ibulah yang digunakan sebagai sarana komunikasi. Kalau ada tokoh masyarakat yang menggunakan bahasa Indonesia, pada umumnya belum memperhatikan kaidah-kaidah berbahasa secara baik dan benar. Akibatnya, siswa tidak terbiasa untuk berbahasa Indonesia sesuai dengan konteks dan situasi tutur.

Dari faktor internal, pendekatan pembelajaran, metode, media, atau sumber pembelajaran yang digunakan oleh guru memiliki pengaruh yang cukup signifikan terhadap tingkat keterampilan bercerita bagi siswa sekolah dasar. Pada umumnya, guru bahasa Indonesia cenderung menggunakan pendekatan yang konvensional dan miskin inovasi sehingga kegiatan pembelajaran keterampilan bercerita berlangsung monoton dan membosankan. Para peserta tidak diajak untuk belajar berbahasa, tetapi cenderung diajak belajar tentang bahasa. Artinya, apa yang disajikan oleh guru di kelas bukan bagaimana siswa bercerita sesuai konteks dan situasi tutur, melainkan diajak untuk mempelajari teori tentang bercerita. Akibatnya, keterampilan bercerita hanya sekadar melekat pada diri siswa sebagai 
sesuatu yang rasional dan kognitif belaka, belum manunggal secara emosional dan afektif. Ini artinya, rendahnya keterampilan bercerita bisa menjadi hambatan serius bagi siswa untuk menjadi siswa yang cerdas, kritis, kreatif, dan berbudaya.

Pembelajaran bahasa Indonesia dewasa ini cenderung kepada pembelajaran bersifat konvensional yaitu hanya menggunakan metode ceramah. Sedangkan pada hakekatnya pembelajaran bahasa Indonesia menuntut siswa dapat berpartisipasi aktif dalam pembelajaran, siswa dapat mencari dan menemukan masalahnya sendiri. Kondisi yang tidak jauh berbeda dapat kita lihat di sekolah-sekolah di sekitar kita, seperti pembelajaran bahasa Indonesia di SDN 1 Pandean Kecamatan Dongko Kabupaten Trenggalek. Tujuan dari penelitian meningkatkan hasil belajar bahasa Indonesia materi tokoh cerita anak dengan metode DRTA (Directed Reading Thinking Activity) pada siswa kelas III SDN 1 Pandean Kecamatan Dongko Semester II Tahun Pelajaran 2016/2017.

\section{METODE}

Penelitian ini dirancang dalam penelitian tindakan kelas dengan mencoba menerapkan model pembelajaran untuk meningkatkan profesionalitas guru sebagai agen dan fasilitator pembelajaran melalui perubahan pelaksanaan proses belajar mengajar menjadi proses pembelajaran. Penelitian Tindakan Kelas merupakan suatu bentuk penelitian yang bersifat reflektif dengan melakukan tindakan-tindakan tertentu agar dapat memperbaiki atau meningkatkan praktek pembelajaran di kelas secara proposional.Di samping itu, penelitian diarahkan untuk meningkatkan prestasi lari jarak pendek melalui latihan akselrasi

Penelitian ini dilaksanakan dengan metode deskriptif kualitatif yaitu untuk mendeskripsikan hasil pembelajaran yang dilakukan guru dalam kelas yang menjadi subjek penelitian. Penelitian tindakan kelas ini dilaksanakan dalam empat tahap, yaitu (1) tahap perencanaan (2) tahap pelaksanaan (3) tahap pengamatan, dan (4) tahap refleksi. Penelitian ini dilaksanakan di SDN 1 Pandean Kecamatan Dongko Kabupaten Trenggalek. Sarana dan prasarananya sangat mendukung untuk dilakukan penelitian tindakan kelas. Halaman sekolah cukup luas, sehingga sangat mendukung pembelajaran penjasorkes. olahraga, kit atletik, dan lain-lain tersedia cukup lengkap. Lapangan olahraga juga sangat memadai untuk pelaksanaan penelitian tentang lari cepat. Subjek Penelitian Tindakan Kelas adalah siswa kelas III SDN 1 Pandean Kecamatan Dongko Semester II Tahun Pelajaran 2016/2017.

\section{Rancangan Penelitian \\ Perencanaan}

Setelah mengkaji hasil identifikasi observasi awal tindakan, dilakukan identifikasi masalah, kajian teori yang relevan, merumuskan focus kajian penelitian. Selanjutnya pembuatan scenario pembelajaran, persiapan sarana dan sumber pembelajaran, persiapan instrument penelitian untuk pembelajaran lanjut. Menyusun rencana tindakan dan penelitian tindakan (termasuk revisi dan perubahan rencana) yang hendak diselenggarakan di dalam pembelajaran. Keduanya disusun secara fleksibel untuk mengadaptasi berbagai pengaruh yang mungkin timbul di lapangan yang tidak dapat diduga maupun kendala yang sebelumnya tidak terlihat. 


\section{Tindakan}

Penentuan perencanaan mengacu pada perencanaan umum (terkait PTK) dan perencanaan khusu (terkait rancangan siklus per siklus). Direncanakan terkait pendekatan pembelajaran, metode pembelajaran, Teknik atau strtategi pembelajaran, media atau materi pembelajaran dan hal lain yang mendukung proses kajian. Proses pembelajaran dilaksanakan mengacun pada Rencana Pelaksanaan Pembelajaran (RPP). Yaitu praktek pembelajaran nyata berdasarkan rencana tindakan yang telah disusun bersama sebelumnya. Tindakan ini ditujukan untuk memperbaiki keadaan atau proses pembelajaran dan hasil belajar siswa.

\section{Refleksi}

Tahapan ini merupakan kegiatan mengevaluasi dan meninjau kembali pel;aksanaan pembelajaran dan hasil observasi yang dilakukan sebagai bahan pertimbangan untuk perbaikan atau perumusan tindakan lebih lanjut. Yaitu menjelaskan tiap kegagalan pelaksanaan dan efek-efek. Berdasarkan periodenya, refleksi pertama dilakukan pada masa studi pendahuluan atau masa pratindakan (refleksi awal). Refleksi kedua dilakukan pada setiap akhir pelaksanaan suatu tindakan (proses atau masalah) persis seperti yang telah dicatat selama observasi. Refleksi dilakukan secara kolaboratif anatara peneliti dengan guru untuk melakukan revisi (perbaikan) pada pelaksanaan tindakan berikutnya.

\section{Teknik Pengumpulan Data}

Teknik pengumpulan data dalam penelitian tindakan kelas ini berupa hasil pengamatan melalui observasi untuk memperoleh data tentang aktivitas belajar siswa selama mengikuti proses pembelajaran. Data yang yang sudah diperoleh kemudian dipaparkan dengan menggunakan statistic deskriptif yang berfungsi memberikan gambaran terhadap objek yang diteliti melalui data sampel yang selanjutnya ditarik kesimpulan. Pelaksanaan penelitian ini menggunakan seperangkat instrument penelitian yang terdiri dari seperangkat tes untuk menguji kemampuan dan hasil belajar siswa dengan adanya pelaksanaan pembelajaran

\section{Teknik Analisis Data}

Penelitian ini menggunakan metode diskriptif dengan cara membandingkan keaktifan dan hasil belajar peserta didik sebelum dan sesudah tindakan pada siklus I dan siklus II. Adapun pengumpulan data yang berbentuk kuantitatif berupa rata-rata yang disajikan berdasarkan angkaangka. Data keaktifan peserta didik perhitungan persentasenya melalui keaktifan peserta didik dalam mengikuti pembelajaran. Data mengenai hasil belajar diambil dari kemampuan kognitif peserta didik dalam memecahkan masalah dianalisis dengan menghitung rata-rata nilai ketuntasan belajar. Menghitung ketuntasan klasikal diperoleh dari hasil belajar dapat ditentukan ketuntasan belajar klasikal menggunakan analisis deskriptif persentase.

\section{HASIL}

Rencana tindakan siklus I, langkah-langkah yang dilakukan dalam rencana tindakan siklus I membuat rencana pembelajaran dengan menggunakan Metode DRTA (Directed Reading Thinking Activity) pada tiap pertemuan, 
membentuk kelompok belajar yang heterogen, menyiapkan alat bantu pengajaran yang diperlukan, membuat lembar observasi untuk mengamati kondisi pembelajaran ketika pelaksanaan tindakan sedang berlangsung, membuat soal tes untuk mengetahui peningkatan hasil belajar pada setiap siklusnya. Observasi hasil pengamatan teman sejawat membahas hasil proses perbaikan pembelajaran pada siklus I, maka ditemukan beberapa kendala yang menjadi permasalahan yaitu pada saat pembentukan kelompok, belum memperhatikan faktor-faktor kedekatan antar anggota dalam kelompoknya, misalnya kedekatan pertemanan dan lokasi tempat tinggal yang dapat memudahkan komunikasi antar anggota kelompok, kurangnya waktu pelaksanaan kegiatan Metode DRTA (Directed Reading Thinking Activity), pemahaman terhadap materi pembelajaran masih kurang, sehingga pada saat pelaksanaan kegiatan Metode DRTA (Directed Reading Thinking Activity) masih banyak siswa yang kurang menghayati peran yang dimainkan, penyusunan naskah masih belum menjurus pada pemahaman konsep pembelajaran sehingga hasil yang diharapkan belum tercapai secara maksimal. Untuk meningkatkan pemahaman terhadap konsep pembelajaran, peneliti dengan observer sepakat perlu dilanjutkan kembali Metode DRTA (Directed Reading Thinking Activity) pada siklus selanjutnya dengan lebih menfokuskan pada penghayatan peran masing-masing tokoh oleh siswa.

Refleksi yang dilakukan menghasilkan rekapitulasi hasil pekerjaaan siswa tentang nilai tes pembelajaran bahasa Indonesia materi tokoh cerita anak pada Siklus I nilai rata-rata hasil belajar secara klasikal sebesar $66,96 \%$ jumlah siswa yang telah mencapai tingkat ketuntasan belajar atau mendapat nilai minimal 69 sebanyak 15 siswa $(65,22 \%)$, dan jumlah siswa yang belum tuntas belajarnya sebanyak 8 siswa atau $34,78 \%$.

Melihat hasil di atas maka peneliti bersama-sama dengan observer sepakat untuk melaksanakan pembelajaran pada siklus II karena jumlah siswa yang mendapat nilai minimal 69 baru mencapai angka 65,22\% dilanjutkan pada siklus II, karena prestasi belajar siswa belum mencapai perolehan di atas KKM sebesar 69,00.

Hasil siklus II setelah mempertimbangkan hasil refleksi pada siklus pertama, maka pada siklus kedua dilaksanakan perbaikan dengan membentuk kelompok dengan memperhatikan faktor-faktor kedekatan antaranggota dalam kelompoknya, misalnya kedekatan pertemanan dan kedekatan lokasi tempat tinggal yang dapat memudahkan komunikasi antar anggota kelompok, hasil yang diharapkan dapat tercapai secara maksimal. Perencanaan, dengan mempertimbangkan hasil refleksi pada siklus pertama, maka pada siklus kedua peneliti mencoba menyempurnakan pelaksanaan perbaikan pembelajaran, dilanjutkan pelaksanaan tindakan, pengamatan tindakan hasil proses perbaikan pembelajaran pada siklus II, maka dapat disimpulkan faktor-faktor yang menyebabkan pelaksanaan pembelajaran pada siklus kedua dapat meningkat dengan baik, yaitu pembentukan kelompok dengan memperhatikan faktor-faktor kedekatan antar anggota dalam kelompoknya, misalnya kedekatan pertemanan dan kedekatan lokasi tempat tinggal yang dapat memudahkan komunikasi antar anggota kelompok. Peneliti menjelaskan kembali materi pembelajaran agar pemahaman terhadap materi pembelajaran masih kurang, sehingga pada saat pelaksanaan kegiatan Metode DRTA (Directed Reading Thinking Activity) masih ada siswa yang kurang menghayati peran yang dimainkan. Penyusunan naskah 
sedetil mungkin agar menjurus pada pemahaman konsep pembelajaran sehingga hasil yang diharapkan tercapai secara maksimal. Pembatasan waktu pelaksanaan kegiatan kegiatan Metode DRTA (Directed Reading Thinking Activity) berjalan dengan baik, dimana tiap kelompok dapat menyelesaikan pementasannya sesuai dengan waktu yang ditentukan.

Refleksi melalui rekapitulasi hasil pekerjaaan siswa didapat pembelajaran bahasa Indonesia materi toko cerita anak pada Siklus II nilai rata-rata hasil belajar secara klasikal sebesar 78,26\% jumlah siswa yang telah mencapai tingkat ketuntasan belajar atau mendapat nilai minimal 69 sebanyak 22 siswa $(95,65 \%)$, dan jumlah siswa yang belum tuntas belajarnya sebanyak 1 siswa atau 4,35\% dan hasil tes hasil belajar menunjukkan hasil 78,26. Hal ini menunjukkan bahwa tes hasil belajar sudah memenuhi kriteria keberhasilan karena hasil belajar berada di atas angka kriteria minimal ketuntasan (KKM) sebesar 69 dan siswa tuntas menunjukkan angka $95,65 \%$ siswa atau 22 orang siswa sehingga proses pembelajaran dinyatakan berhasil dan tuntas pada pelaksanaan siklus II karena sudah berada di atas kriteria keberhasilan sebesar $85 \%$.

\section{PEMBAHASAN}

Pada siklus I menggunakan metode pembelajaran klasikal, ternyata hasil ketuntasan belajar sangat mengecewakan, yaitu 4 siswa atau sebesar 17,39\% yang tuntas belajar dari 23 orang siswa yang mengikuti kegiatan pembelajaran dengan perolehan nilai rata-rata hasil belajar sebesar 56,52. Pada siklus I peneliti dalam pembentukan kelompok, belum memperhatikan faktor-faktor kedekatan antaranggota dalam kelompoknya, misalnya kedekatan pertemanan dan kedekatan lokasi tempat tinggal yang dapat memudahkan komunikasi antar anggota kelompok ternyata hasil yang diharapkan belum tercapai secara maksimal. Untuk meningkatkan pemahaman terhadap konsep pembelajaran, peneliti dengan observer sepakat perlu dilanjutkan kembali DRTA (Directed Reading Thinking Activity) pada siklus selanjutnya dengan lebih menfokuskan pada penghayatan peran masing-masing tokoh oleh siswa.

Pembelajaran Bahasa Indonesia materi menceritakan peristiwa pada kegiatan perbaikan pembelajaran pada siklus pertama belum mencapai kriteria yang ditentukan. Pada siklus pertama, dengan menerapkan kegiatan DRTA (Directed Reading Thinking Activity) secara berkelompok, ternyata hasil ketuntasan belajar mencapai 15 siswa $(65,22 \%)$ yang dinyatakan tuntas dari 23 orang siswa yang mengikuti pembelajaran.

Pada siklus II peneliti lebih mengintensifkan upaya untuk menjelaskan kembali materi pembelajaran agar pemahaman terhadap materi pembelajaran masih kurang, menambah waktu latihan bagi siswa sehingga pada saat pelaksanaan pentas, masih ada beberapa siswa yang tampak grogi dan kurang bisa menghayati peran yang dimainkan, serta memberikan rambu-rambu pembatasan waktu pelaksanaan kegiatan kegiatan DRTA (Directed Reading Thinking Activity) berjalan dengan baik, dimana tiap kelompok dapat menyelesaikan. Hampir semua tujuan telah tercapai sesuai dengan kriteria keberhasilan yang ditentukan. Berdasarkan hasil pengolahan data-data dan hasil observasi dilakukan analisis dan dapat diketahui bahwa semua tujuan telah tercapai sesuai dengan kriteria keberhasilan yang ditentukan. Hal ini dapat dibuktikan dengan pembelajaran berlangsung sangat kondusif dan interaktif. Siswa tampak senang 
belajar. Hal ini tampak dari kesungguhan siswa dalam melaksanakan tugas berupa kegiatan DRTA (Directed Reading Thinking Activity) yang diberikan guru, dan siswa nampak antusias dan bersemangat dalam pelaksanaan kegiatan DRTA (Directed Reading Thinking Activity), hal ini dibuktikan dengan tingkat penghayatan peran yang semakin baik.

Hasil hasil belajar menunjukkan bahwa dari hasil tes terdapat 22 orang siswa $(95,65 \%)$ dinyatakan tuntas belajar dari sebanyak 23 orang siswa yang mengikuti proses pembelajaran dengan nilai rata-rata sebesar 78,26. Setelah dilakukan analisa terhadap data yang diperoleh peningkatan ketuntasan belajar dan nilai rata-rata hasil belajar siswa pada setiap siklus pelaksanaan kegiatan penelitian tindakan kelas dengan menerapkan metode Metode DRTA (Directed Reading Thinking Activity). Metode DRTA (Directed Reading Thinking Activity) terbukti mampu meningkatkan hasil belajar siswa dari rata-rata pada studi awal hanya 56,52 naik menjadi 66,96 pada siklus pertama, dan 78,26 pada siklus kedua, dengan tingkat ketuntasan belajar sebanyak 4 siswa $(17,39 \%)$ pada studi awal, 65,22\% atau 15 siswa pada siklus pertama, 22 siswa atau 95,65\% pada siklus kedua.

\section{KESIMPULAN}

Berdasarkan data-data hasil pelaksanaan perbaikan pembelajaran sebagaimana diuraikan di atas berupa data hasil tes siklus I, tes siklus II dan data maka dapat disimpulkan bahwa model pembelajaran DRTA dapat meningkatkan hasil belajar Bahasa Indonesia Materi tokoh cerita anak siswa pada siswa kelas III SDN 1 Pandean Kecamatan Dongko Kabupaten Trenggalek Tahun Pelajaran 2016/2017.

\section{SARAN}

Saran yang dapat disampaikan diharapkan pengarahan pada siswa untuk terlibat secara aktif dengan dukungan alat peraga, media pembelajaran dan metode yang mengaktifkan siswa. Selanjutnya hendaknya siswa dapat meningkatkan kemampuan memahami materi pembelajaran dengan cara bekerja sama dalam suatu kelompok yang menyenangkan dengan melaksanakan kegiatan bermain peran. Bagi guru sebagai pendidik dan pengembang bakat dan minat hendaknya membuat rencana pembelajaran sebelum melaksanakan pembelajaran dan menghindari kecenderungan mengejar target pencapaian kurikulum, karena muatan kurikulum sudah di perhitungkan berdasarkan alokasi waktu dan hari efektif. Kecenderungan ini menyebabkan pembelajaran bahasa Indonesia menjadi monoton sehingga membosankan siswa. Guru dituntut lebih kreatif mengembangkan model pembelajaran serta mencari informasi-informasi terkini yang berkaitan dengan pembelajaran bahasa Indonesia dan mampu menciptakan suasana pembelajaran yang aktif, kreatif, inovatif dan menyenangkan melalui pemilihan metode pembelajaran yang tepat sehingga dapat memberikan hasil belajar yang baik. Bagi sekolah sebagai institusi diharapkan dapat memotivasi, memfasilitasi, memberi bimbingan dan kesempatan kepada guru untuk menggunakan berbagai media pembelajaran inovatif yang dapat meningkatkan minat, aktivitas dan prestasi belajar siswa. Hasil penelitian ini, disarankan dapat didesiminasikan (disebarluaskan) kepada guru lain, agar hasil penelitian dapat 
digenaralisasikan hasilnya, apabila sudah diterapkan pada kelas lain dan menunjukkan hasil yang sama.

\section{DAFTAR RUJUKAN}

Permatasari, I. 2009. Pengembangan Strategi Penggunaan Gambar Seri untuk Meningkatkan Kemampuan Bercerita Siswa MTs Negeri Batu Tahun Ajaran 2008/2009. Skripsi tidak diterbitkan. Malang: Fakultas Sastra Universitas Negeri Malang.

Widyamartaya, A. 1984. Kreatif Berwicara. Yogyakarta: Yayasan Kanisius.

Sudarmadji, Mahmoud, H., Fanani, R. Z., Nahiruddin, Syamsuddin, U., Sugito, Priyana, N., dan Sugani. 2010. Teknik Bercerita. Yogyakarta: PT Kurnia Kakam Semesta. 